\title{
Cardiomegaly of unknown origin among Nigerian adults: role of hypertension in its aetiology
}

\author{
A. O. FALASE \\ From the Department of Medicine, University College Hospital, Ibadan, Nigeria
}

Fifty Nigerians with cardiomegaly of unknown origin were followed up over a period of 1 to 4 years. This condition was defined as congestive cardiac failure and cardiac enlargement of unknown cause with a presenting diastolic blood pressure of not more than $100 \mathrm{mmHg}$. Twenty-four of the patients presented with a normal blood pressure (diastolic blood pressure below $90 \mathrm{mmHg}$ ) and 26 with a diastolic blood pressure of 90 to $100 \mathrm{mmHg}$. Each patient was initially treated in hospital with digoxin and frusemide and followed up as an out-patient. Of the 24 normotensive patients, 18 remained normotensive throughout the entire observation period. Heart failure was controlled with digoxin and frusemide both as an in-patient and in the subsequent out-patient follow-up. The heart failure of the remaining 6 patients was controlled in hospital but they developed high blood pressures and relapsed into heart failure during out-patient follow-up on digoxin and frusemide. They needed antihypertensive therapy in the form of thiazides or methyldopa and thiazides to keep them out of heart failure. Twenty patients with initially raised blood pressures responded to in-patient treatment with a fall in blood pressure and remission of their cardiac failure. During out-patient follow-up the blood pressure became raised again and cardiac failure reappeared. These patients also needed antihypertensive therapy to produce a sustained fall in blood pressure and relief of their heart failure. Six other patients who presented with raised blood pressures did not respond even as in-patients until antihypertensive therapy had been instituted.

It is concluded that not all Nigerians with cardiomegaly of unknown origin are hypertensives. The mild hypertension seen in some of the patients contributes to their morbidity and is not a result of their heart failure. Hypertension, however, is probably not the sole cause of their heart failure but acts in concert with other factors to produce their severe myocardial damage.

There have been various descriptions of the pathology, haemodynamics, clinical, radiological, and electrocardiographic features of cardiomegaly of unknown origin from different parts of the world (Reisinger and Blumenthal, 1941; Higginson et al., 1952; Becker et al., 1953; Brigden, 1957; Mattingly, 1961; Edington and Jackson, 1963; Stuart and Hayes, 1963; World Health Organization, 1965; Cockshott et al., 1967; Edington and Hutt, 1968; Parry, 1968; Antia, 1968; Goodwin and Oakley, 1972; Goodwin, 1972a). One of the recognised features of this disease is a transient rise in diastolic blood pressure, the rise in pressure usually being limited to the period of congestive cardiac failure (Reisinger and Blumenthal, 1941; Brigden, 1957; Stuart and Hayes, 1963; Fowler, 1964; World Health Organization, 1965; Tobin et al., 1967; Parry, 1968). With response to treatment of the heart failure, the diastolic pressure tends to return Received for publication 26 October 1976 to normal. No other evidence of hypertension is found, apart from minor arterial changes in the ocular fundi (Parry, 1968). The transient rise in blood pressure also called reactive hypertension (Akinkugbe, 1972; Brockington, 1974) is usually regarded as secondary to heart failure, lasting as long as the heart is in failure, with the primary pathology being in the myocardium (Fishberg, 1940; Davies et al., 1951; Fowler, 1964; Harvey et al., 1964; Massumi et al., 1965; Akinkugbe, 1972).

Oakley (1972) and Brockington (1972), however, recently suggested that cardiomegaly of unknown origin is a disguised variant of hypertensive heart disease, a view that was challenged by Goodwin (1972b). Later, Brockington (1974), in a comparative study of the epidemiology, clinical manifestations, pathology, and aortic diameters on chest radiographs of patients with hypertensive heart failure and cardiomegaly of unknown origin, came to the 
conclusion that the latter is a late stage of untreated hypertension.

At the University College Hospital, Ibadan, Nigeria, cardiomegaly of unknown origin, otherwise known as 'heart muscle disease', is the diagnosis most often made in adults presenting with heart failure, and it is the second cause of death from heart disease in our population (Brockington and Bohrer, 1970). Fifty Nigerians with cardiomegaly of unknown origin who were recently admitted to our wards afforded us the opportunity to study their natural history in some detail. This paper describes our findings in the evaluation of the role of hypertension in the aetiology of cardiomegaly of unknown origin.

\section{Subjects and methods}

The patients were diagnosed as suffering from cardiomegaly of unknown origin if they had congestive cardiac failure and cardiac enlargement confirmed by plain $x$-ray film of the chest, and if the known causes of heart failure or enlargement such as anaemia, congenital heart disease, organic valvular disease, endomyocardial fibrosis, and obstructive hypertrophic cardiomyopathy had been excluded on clinical grounds. They were unselected and constituted a consecutive series admitted either as emergencies or from the out-patient clinic.

Only patients with a presenting diastolic blood pressure of $100 \mathrm{mmHg}$ and below were admitted to the study. Patients with higher diastolic blood pressures were diagnosed as having hypertensive heart failure.

Inquiries were made from each patient about alcohol ingestion, family illness, type of diet, annual income, and, where applicable, number of pregnancies. Further confirmation of the alcohol and family history was obtained in the majority of them from their relatives and friends. This was necessary because many of the patients were reluctant to disclose information about their family and sometimes told lies about their alcohol intake. Consumption of at least $2000 \mathrm{ml}$ beer or palm-wine or $375 \mathrm{ml}$ spirits daily for over 5 years was considered as a heavy and prolonged intake of alcohol. All the patients were classified into upper and lower socioeconomic groups as defined by Osuntokun et al. (1971).

Each patient on admission was given digitalis and frusemide $80 \mathrm{mg}$ daily. This dose of frusemide was increased up to $240 \mathrm{mg}$ daily if there was no improvement. Frusemide was chosen because of its small antihypertensive effect when compared with thiazides (Anderson et al., 1971). The patients were maintained on the same dose of drugs on discharge from hospital. Thiazides and when necessary methyldopa were substituted for frusemide if the blood pressure remained high.

On recovery from heart failure, 20 of the patients (12 men and 8 women) were readmitted and observed on maintenance digoxin alone. Each of them was allowed liberal use of salt in his food. Their blood pressures and pulse rates were carefully monitored daily. The original treatment was resumed when they relapsed into heart failure. Blood pressures were recorded in the supine position after 3 minutes of rest using a mercury sphygmomanometer. The first and the fifth Korotkoff sounds were used as measures of systolic and diastolic blood pressures. Blood pressures were recorded by the author only, in order to eliminate observer variation.

All the patients had chest $x$-ray examinations, electrocardiograms, erythrocyte sedimentation rates, urinalyses, haemoglobin and packed cell volume estimations, leucocyte counts, electrolyte and urea analyses, serum protein analyses, and liver function tests. Of the 50 patients, 33 had cardiac catheterisation and angiography. All the patients were followed up for periods ranging from 1 year to 4 years.

\section{Results}

The 50 patients were made up of 28 women and 22 men. Their age and sex distribution is shown in Fig. 1.

\section{PRESENTING BLOOD PRESSURE}

Of the 50 patients, 24 (group A) presented with diastolic blood pressures below $90 \mathrm{mmHg}$. The remaining 26 patients (group B) presented with diastolic blood pressures between $90 \mathrm{mmHg}$ and $100 \mathrm{mmHg}$. Their presenting systolic pressures are shown in Table 1.

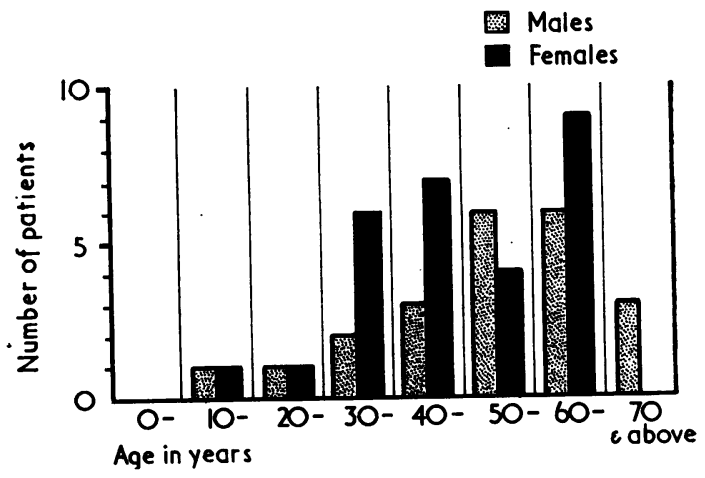

Fig. 1 Age and sex distribution of the 50 patients 
Table 1 Presenting systolic pressures in 50 patients

\begin{tabular}{lc}
\hline Systolic blood pressure $(\mathrm{mmHg})$ & No. of patients \\
\hline 100 and below & 4 \\
$101-110$ & 11 \\
$111-120$ & 8 \\
$121-130$ & 16 \\
$131-140$ & 7 \\
$141-150$ & 1 \\
$151-160$ & 3 \\
\hline
\end{tabular}

\section{CLINICAL COURSE}

Group $A$

Eighteen (Group A1; Table 2) of these patients remained normotensive on digoxin and frusemide both as in-patients and out-patients. The remaining
6 patients (group A2; Table 3) on admission responded similarly to digitalis and frusemide but as out-patients relapsed on these drugs into congestive cardiac failure with raised blood pressures. They subsequently improved when their diuretics were changed to thiazides. One of them (case 22) also required methyldopa to keep him out of heart failure.

\section{Group B}

Twenty (group B1; Table 4) of the patients in this group improved on digitalis and frusemide as inpatients. Their diastolic blood pressures returned to normal within a week. However, on discharge from hospital and on the same dose of drugs as at discharge, they relapsed into heart failure with raised

Table 2 Summary of clinical course of patients in group A1, on digoxin and frusemide as in-patients and at first visit as out-patients

\begin{tabular}{|c|c|c|c|c|c|c|c|c|c|c|c|c|c|}
\hline \multirow[t]{2}{*}{$\begin{array}{l}\text { Case } \\
\text { No. }\end{array}$} & \multicolumn{4}{|c|}{ Findings at admission } & \multicolumn{4}{|c|}{$\begin{array}{l}\text { In-patient findings just before } \\
\text { discharge }\end{array}$} & \multicolumn{4}{|c|}{ First visit as out-patient } & \multirow[t]{2}{*}{ Remarks } \\
\hline & $C C F$ & $\begin{array}{l}\text { Apical } \\
\text { PSM }\end{array}$ & $\begin{array}{l}\text { 3rd } \\
\text { sound }\end{array}$ & $\begin{array}{l}B P \\
(m m H g)\end{array}$ & $C C F$ & $\begin{array}{l}\text { Apical } \\
\text { PSM }\end{array}$ & $\begin{array}{l}\text { 3rd } \\
\text { sound }\end{array}$ & $\begin{array}{l}B P \\
(m m H g)\end{array}$ & $C C F$ & $\begin{array}{l}\text { Apical } \\
\text { PSM }\end{array}$ & $\begin{array}{l}\text { 3rd } \\
\text { sound }\end{array}$ & $\begin{array}{l}B P \\
(m m H g)\end{array}$ & \\
\hline 1 & + & - & + & $120 / 80$ & - & - & + & $120 / 80$ & 一 & 一 & + & $100 / 60$ & $\begin{array}{l}\text { Subsequently developed tricuspid } \\
\text { regurgitation }\end{array}$ \\
\hline 2 & + & + & + & $110 / 70$ & 一 & - & - & $110 / 70$ & - & - & - & $120 / 75$ & \\
\hline 3 & + & 一 & + & $90 / 55$ & 一 & - & + & $100 / 60$ & 一 & - & + & $100 / 60$ & Tricuspid regurgitation also \\
\hline 4 & + & + & + & $130 / 80$ & - & + & + & $125 / 85$ & 一 & - & + & $120 / 80$ & Tricuspid regurgitation also \\
\hline 5 & + & + & + & $110 / 70$ & - & + & - & $110 / 75$ & 一 & + & - & $120 / 70$ & \\
\hline 6 & + & - & + & $120 / 80$ & 一 & - & - & $100 / 60$ & - & - & - & $110 / 70$ & \\
\hline 7 & + & + & + & $110 / 80$ & - & - & - & $130 / 85$ & - & - & - & $120 / 80$ & \\
\hline 8 & + & + & + & $120 / 85$ & - & + & + & $120 / 80$ & - & + & + & $110 / 70$ & \\
\hline 9 & + & - & + & $110 / 70$ & - & - & + & $110 / 80$ & - & - & + & $120 / 75$ & \\
\hline 10 & + & - & + & $100 / 70$ & - & - & + & $110 / 75$ & - & - & + & $110 / 70$ & Later developed tricuspid regurgitation \\
\hline 11 & + & + & + & $110 / 65$ & - & + & + & $110 / 60$ & - & + & + & $110 / 75$ & Tricuspid regurgitation also \\
\hline 12 & + & - & + & $130 / 70$ & - & 一 & + & $110 / 70$ & 一 & 一 & + & $120 / 80$ & Tricuspid regurgitation also \\
\hline 13 & + & + & + & $120 / 80$ & - & + & + & $110 / 70$ & - & + & + & $120 / 80$ & Tricuspid regurgitation also \\
\hline 14 & + & + & + & $130 / 80$ & - & + & + & $120 / 75$ & - & + & + & $120 / 70$ & \\
\hline 15 & + & + & + & $125 / 85$ & - & + & + & $110 / 70$ & - & + & + & $120 / 70$ & \\
\hline 16 & + & + & + & $90 / 70$ & - & + & + & $190 / 75$ & - & + & + & $100 / 60$ & \\
\hline 17 & + & + & + & $110 / 85$ & - & + & + & $120 / 80$ & - & + & + & $120 / 80$ & \\
\hline 18 & + & + & + & $95 / 60$ & - & + & + & $100 / 60$ & - & + & + & $100 / 60$ & \\
\hline
\end{tabular}

CCF, congestive cardiac failure; PSM, pansystolic murmur; BP, blood pressure.

Table 3 Summary of clinical course of patients in group A2, on digoxin and frusemide as in-patients and at first visit as out-patients

\begin{tabular}{|c|c|c|c|c|c|c|c|c|c|c|c|c|c|}
\hline \multirow[t]{2}{*}{$\begin{array}{l}\text { Case } \\
\text { No. }\end{array}$} & \multicolumn{4}{|c|}{ Findings at admission } & \multicolumn{4}{|c|}{$\begin{array}{l}\text { In-patient findings just before } \\
\text { discharge }\end{array}$} & \multicolumn{4}{|c|}{ First visit as out-patient } & \multirow[t]{2}{*}{ Remarks } \\
\hline & $C C F$ & $\begin{array}{l}\text { Apical } \\
\text { PSM }\end{array}$ & $\begin{array}{l}\text { 3rd } \\
\text { sound }\end{array}$ & $\begin{array}{l}B P \\
(m m H g)\end{array}$ & $C C F$ & $\begin{array}{l}\text { Apical } \\
\text { PSM }\end{array}$ & $\begin{array}{l}\text { 3rd } \\
\text { sound }\end{array}$ & $\begin{array}{l}B P \\
(m m H g)\end{array}$ & $C C F$ & $\begin{array}{l}\text { Apical } \\
P S M\end{array}$ & $\begin{array}{l}\text { 3rd } \\
\text { sound }\end{array}$ & $\begin{array}{l}B P \\
(m m H g)\end{array}$ & \\
\hline 19 & + & + & + & $105 / 70$ & - & - & - & $110 / 80$ & + & + & + & $130 / 100$ & Improved on thiazides \\
\hline 20 & + & + & + & $110 / 70$ & - & - & - & $100 / 80$ & + & - & + & $140 / 105$ & Improved on thiazides \\
\hline 21 & + & + & + & $140 / 80$ & - & - & - & $130 / 80$ & + & - & + & $160 / 100$ & Improved on thiazides \\
\hline 22 & + & + & + & $120 / 85$ & - & - & - & $120 / 75$ & + & - & + & $150 / 110$ & $\begin{array}{l}\text { Improved on methyldopa and } \\
\text { thiazides }\end{array}$ \\
\hline 23 & + & - & + & $120 / 80$ & - & - & - & $120 / 80$ & + & - & + & $130 / 115$ & Improved on thiazides \\
\hline 24 & + & + & + & $110 / 80$ & - & - & + & $100 / 80$ & + & + & + & $130 / 100$ & Improved on thiazides \\
\hline
\end{tabular}


Table 4 Summary of clinical course of patients in group B1 on same dose of digoxin and frusemide as in-patients and as out-patients

\begin{tabular}{|c|c|c|c|c|c|c|c|c|c|c|c|c|c|}
\hline \multirow[t]{2}{*}{$\begin{array}{l}\text { Case } \\
\text { No. }\end{array}$} & \multicolumn{4}{|c|}{ Findings at admission } & \multicolumn{4}{|c|}{$\begin{array}{l}\text { In-patient findings just before } \\
\text { discharge }\end{array}$} & \multicolumn{4}{|c|}{ First visit as out-patient } & \multirow[t]{2}{*}{ Remarks } \\
\hline & $C C F$ & $\begin{array}{l}\text { Apical } \\
\text { PSM }\end{array}$ & $\begin{array}{l}\text { 3rd } \\
\text { sound }\end{array}$ & $\begin{array}{l}B P \\
(m m H g)\end{array}$ & CCF & $\begin{array}{l}\text { Apical } \\
\text { PSM }\end{array}$ & $\begin{array}{l}\text { 3rd } \\
\text { sound }\end{array}$ & $\begin{array}{l}B P \\
(\operatorname{man} H g)\end{array}$ & $C C F$ & $\begin{array}{l}\text { Apical } \\
\text { PSM }\end{array}$ & $\begin{array}{l}\text { 3rd } \\
\text { sound }\end{array}$ & $\begin{array}{l}B P \\
(m m H g)\end{array}$ & \\
\hline 25 & + & + & + & $135 / 90$ & - & + & + & $110 / 80$ & + & + & + & $120 / 100$ & Improved on thiazides \\
\hline 26 & + & + & + & $130 / 90$ & - & - & - & $110 / 70$ & + & + & + & $150 / 105$ & Improved on thiazides \\
\hline 27 & + & + & + & $130 / 95$ & 一 & 一 & - & $120 / 80$ & + & + & + & $140 / 100$ & Improved on thiazides \\
\hline 28 & + & + & + & $160 / 90$ & - & 一 & 一 & $120 / 80$ & + & + & + & $170 / 100$ & Improved on thiazides \\
\hline 29 & + & + & + & $110 / 90$ & - & - & - & $100 / 70$ & + & + & + & $120 / 100$ & Improved on thiazides \\
\hline 30 & + & + & + & $130 / 90$ & - & - & 一 & $115 / 75$ & + & - & + & $170 / 100$ & Improved on thiazides \\
\hline 31 & + & + & + & $130 / 90$ & 一 & 一 & - & $110 / 80$ & + & + & + & $130 / 95$ & Improved on thiazides \\
\hline 32 & + & 一 & + & $145 / 100$ & - & 一 & 一 & $130 / 80$ & + & + & + & $140 / 105$ & $\begin{array}{l}\text { Improved on methyldopa and } \\
\text { thiazides }\end{array}$ \\
\hline 33 & + & + & + & $125 / 100$ & 一 & + & + & $120 / 80$ & + & + & + & $140 / 105$ & $\begin{array}{l}\text { Improved on methyldopa and } \\
\text { thiazides }\end{array}$ \\
\hline 34 & + & + & + & $140 / 100$ & - & - & - & $120 / 70$ & + & + & + & $140 / 105$ & Improved on thiazides \\
\hline 35 & + & + & + & $110 / 100$ & 一 & 一 & 一 & $130 / 80$ & + & + & + & $140 / 100$ & $\begin{array}{l}\text { Improved on thiazides, had tricuspid } \\
\text { regurgitation also }\end{array}$ \\
\hline 36 & + & + & + & $135 / 100$ & - & 一 & 一 & $120 / 70$ & + & 一 & + & $210 / 110$ & $\begin{array}{l}\text { Improved on methyldopa and } \\
\text { thiazides }\end{array}$ \\
\hline 37 & + & 一 & + & $140 / 100$ & 一 & - & + & $120 / 80$ & + & 一 & + & $150 / 110$ & $\begin{array}{l}\text { Improved on methyldopa and } \\
\text { thiazides }\end{array}$ \\
\hline 38 & + & + & + & $120 / 100$ & - & 一 & - & $105 / 85$ & + & + & + & $120 / 100$ & Improved on thiazides \\
\hline 39 & + & - & + & $120 / 100$ & - & - & - & $105 / 80$ & 一 & 一 & + & $135 / 105$ & Improved on thiazides \\
\hline 40 & + & - & + & $160 / 100$ & - & 一 & - & $150 / 80$ & + & - & + & $170 / 100$ & Improved on thiazides \\
\hline 41 & + & 一 & + & $140 / 100$ & - & 一 & 一 & $120 / 70$ & + & 一 & + & $170 / 105$ & Improved on thiazides \\
\hline 42 & + & + & + & $130 / 100$ & - & 一 & + & $100 / 60$ & + & + & + & $170 / 95$ & $\begin{array}{l}\text { Improved on thiazides; had tricuspid } \\
\text { regurgitation in addition }\end{array}$ \\
\hline 43 & + & + & + & $130 / 90$ & 一 & 一 & + & $120 / 80$ & + & + & + & $140 / 100$ & Improved on thiazides \\
\hline 44 & + & + & + & $120 / 100$ & 一 & 一 & + & $130 / 80$ & + & + & + & $140 / 110$ & Improved on thiazides \\
\hline
\end{tabular}

CCF, congestive cardiac failure; PSM, pansystolic murmur; BP, blood pressure.

Table 5 Summary of clinical course of patients in group B2

\begin{tabular}{|c|c|c|c|c|c|c|c|c|c|c|c|c|c|c|c|c|}
\hline \multirow[t]{2}{*}{$\begin{array}{l}\text { Case } \\
\text { No. }\end{array}$} & \multicolumn{4}{|c|}{ Findings at admission } & \multicolumn{4}{|c|}{$\begin{array}{l}\text { In-patient treatment } \\
\text { (1) }\end{array}$} & \multicolumn{4}{|l|}{ (2) } & \multicolumn{4}{|c|}{$\begin{array}{l}\text { Out-patient } \\
\text { (3) }\end{array}$} \\
\hline & $C C F$ & $\begin{array}{l}\text { Apical } \\
P S M\end{array}$ & $\begin{array}{l}\text { 3rd } \\
\text { sound }\end{array}$ & $\begin{array}{l}B P \\
(m \boldsymbol{m H g})\end{array}$ & $C C F$ & $\begin{array}{l}\text { Apical } \\
\text { PSM }\end{array}$ & $\begin{array}{l}\text { 3rd } \\
\text { sound }\end{array}$ & $\begin{array}{l}B P \\
(m m H g)\end{array}$ & $C C F$ & $\begin{array}{l}\text { Apical } \\
\text { PSM }\end{array}$ & $\begin{array}{l}\text { 3rd } \\
\text { sound }\end{array}$ & $\begin{array}{l}B P \\
(m m H g)\end{array}$ & $C C F$ & $\begin{array}{l}\text { Apical } \\
P S M\end{array}$ & $\begin{array}{l}\text { 3rd } \\
\text { sound }\end{array}$ & $\begin{array}{l}B P \\
(m m H g)\end{array}$ \\
\hline $\begin{array}{l}45 \\
46 \\
47 \\
48 \\
49 \\
50\end{array}$ & $\begin{array}{l}+ \\
+ \\
+ \\
+ \\
+ \\
+\end{array}$ & $\frac{+}{ \pm}$ & $\begin{array}{l}+ \\
+ \\
+ \\
+ \\
+ \\
+\end{array}$ & $\begin{array}{l}130 / 100 \\
160 / 90 \\
130 / 95 \\
140 / 100 \\
130 / 100 \\
130 / 100\end{array}$ & $\begin{array}{l}+ \\
+ \\
+ \\
+ \\
+ \\
+\end{array}$ & $\frac{-}{ \pm}+$ & $\begin{array}{l}+ \\
+ \\
+ \\
+ \\
+\end{array}$ & $\begin{array}{l}130 / 105 \\
150 / 105 \\
170 / 100 \\
140 / 100 \\
150 / 110 \\
140 / 105\end{array}$ & $\begin{array}{l}- \\
z \\
z\end{array}$ & $\begin{array}{l}- \\
\pm \\
\pm \\
-\end{array}$ & $\begin{array}{l}\overline{-} \\
\pm \\
\pm\end{array}$ & $\begin{array}{l}120 / 85 \\
170 / 75 \\
140 / 85 \\
110 / 75 \\
120 / 85 \\
110 / 80\end{array}$ & $\begin{array}{l}z \\
z \\
z\end{array}$ & $\begin{array}{l}\bar{z} \\
\bar{z} \\
-\end{array}$ & $\begin{array}{l}\frac{-}{+} \\
\frac{+}{-}\end{array}$ & $\begin{array}{l}120 / 80 \\
150 / 70 \\
150 / 95 \\
150 / 80 \\
120 / 100 \\
130 / 85\end{array}$ \\
\hline
\end{tabular}

(1) Response to digoxin and frusemide; (2) Response to thiazides (case 45) or alpha methyldopa and thiazides (remaining patients); (3) Subsequent reponse as out-patients; patients were on the same drugs as in (2).

CCF, congestive cardiac failure; PSM, pansystolic murmur; BP, blood pressure.

blood pressures. Of the 20 patients, 16 subsequently improved when their diuretics were changed to thiazides. The remaining 4 patients required methyldopa in addition to thiazides to improve their heart failure. These 4 patients subsequently remained well on these drugs without added digoxin.

The remaining 6 patients (group B2; Table 5) in group B showed no response to digoxin and frusemide as in-patients. Their diastolic blood pressures remained persistently raised throughout the period they were in failure. One of them improved when his diuretic was changed to hydrochlorothiazide. The other 5 patients required methyldopa in addition to thiazide diuretics to improve their heart failure.

PATIENTS ON DIGOXIN WITHOUT DIURETICS Fig. $2 a$ and $2 b$ show the behaviour of the blood pressures of 20 patients, who after recovery were readmitted to hospital and observed on digoxin alone, with no salt restriction. Eight of them were 

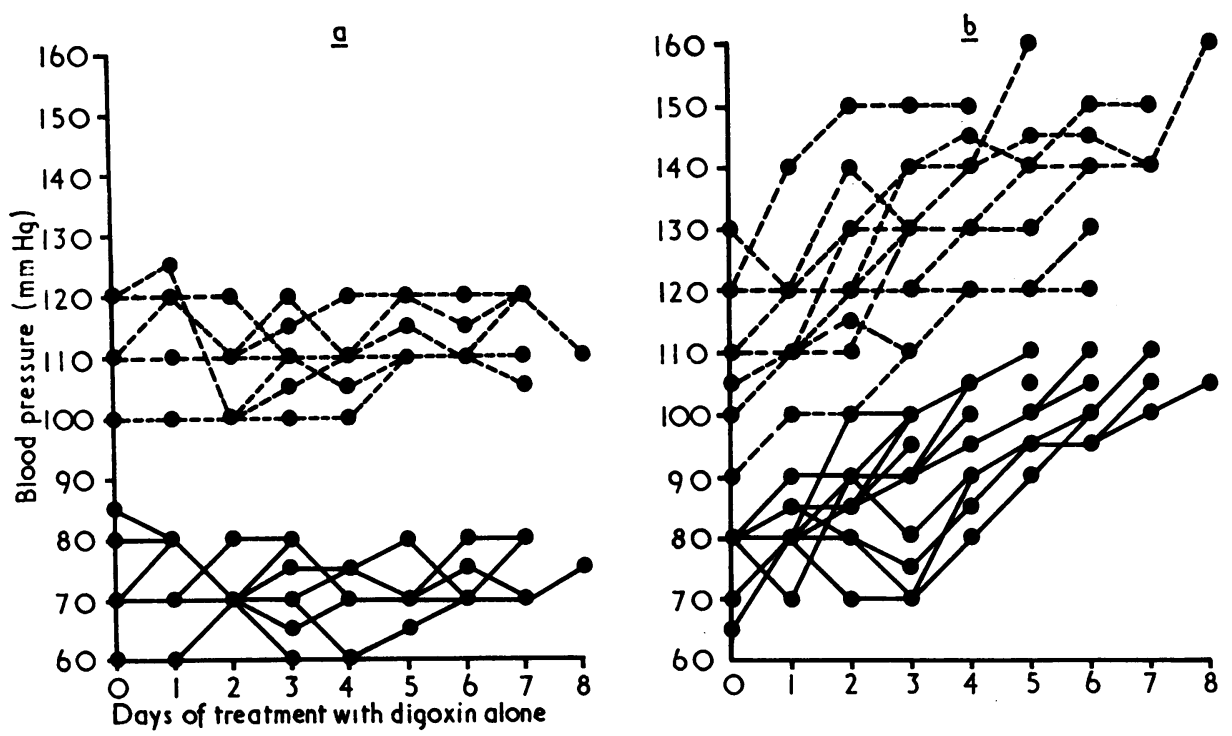

Fig. 2 (a) Behaviour of the blood pressures of 8 patients who were normotensive throughout. (b) 12 patients who responded with mild hypertension to digoxin alone without diuretics or restricted salt intake.

from group A1, 2 from group A2, 8 from group B1, and 2 from group B2. They had all previously been seen as in-patients, then discharged, and observed for varying periods as out-patients before their readmission.

All the 20 patients had symptoms of heart failure between the fourth and the seventh day of readmission. The 8 patients in group A1 however had no previous rise in blood pressure before they had symptoms of heart failure (Fig. 2a). The remaining 12 patients on the other hand had an initial rise in blood pressure (Fig. 2b). The following is an illustrative case report.

\section{Case report}

A woman of 50 years was admitted 3 months previously in congestive heart failure with mitral regurgitation and a loud third sound. Her blood pressure then was $140 / 100 \mathrm{mmHg}$. She subsequently improved on digoxin and hydrochlorothiazide ( $100 \mathrm{mg}$ daily). At the time of her second admission, she was free of heart failure, her blood pressure was $120 / 80 \mathrm{mmHg}$, she had no third heart sound, and no apical systolic murmur. Her hydrochlorothiazide was then stopped and she was allowed liberal use of salt.

Three days afterwards, her blood pressure was $120 / 95 \mathrm{mmHg}$, and a fourth sound was heard at the apex together with a soft midsystolic murmur. Two days after this, her blood pressure was 140/100 $\mathrm{mmHg}$, her systolic murmur was louder, and both third and fourth sounds were audible. Seven days after her diuretics were stopped, she complained of dyspnoea. Her blood pressure was $150 / 110 \mathrm{mmHg}$, her jugular venous pressure was raised and a loud third heart sound together with a midsystolic murmur were heard at the apex. Her pulmonary closure sound was louder but she had no crepitations in the chest. She subsequently improved when hydrochlorothiazide (100 mg daily) was again started.

\section{CLINICAL FEATURES}

All the 50 patients were admitted in congestive heart failure. Symptoms of left heart failure predominated. The duration of symptoms ranged between 2 and 84 months with a mean of 11 months. Twenty-seven $(54 \%)$ of them gave a history of chest pain at onset of illness. In 16 of these, the chest pain was a vague discomfort not typically anginal. The remaining 11 had a pleuritic type of chest pain. Twenty patients $(40 \%)$ volunteered a history of febrile illness before the onset of their symptoms. Seventeen patients $(34 \%)$ had paraesthesiae.

One patient had been treated for heart failure 11 years previously. She received only digoxin at the time and improved subsequently. Thirteen patients $(26 \%)$ belonged to the high socioeconomic group.

\section{DIET}

The diet of patients from the low socioeconomic group consisted largely of carbohydrates with low 
protein and fat content. The diet of the higher socioeconomic group resembled those in the lower socioeconomic group but with more animal protein and animal fat.

\section{ALCOHOL}

Twenty $(40 \%)$ of the patients (16 men and 4 women) gave a history of excessive and prolonged intake of alcohol; 14 of them required thiazide diuretics or, in addition, methyldopa to keep them out of heart failure. The remaining 6 patients were normotensive as in-patients and out-patients. All the 13 patients who belonged to the high socioeconomic group in this study misused alcohol. The patients in the low socioeconomic group consumed mainly locally-brewed alcoholic beverages which were cheaper, easily obtainable, but nonstandardised. Those in the high socioeconomic group consumed mainly imported alcoholic beverages (beer, wine, spirits) though some of them misused locally brewed alcoholic drinks as well.

\section{PARITY}

Twenty ( $71 \%$ ) of the 28 female patients have had 5 pregnancies or more. One had never been pregnant. Only 1 patient had symptoms of heart failure within 6 months of delivery.

\section{FAMILY HISTORY}

Two patients had strong family histories of hypertension. One other female patient had a husband who was hypertensive and both of them drank alcohol excessively.

\section{NUTRITIONAL STATUS}

Thirty-three $(66 \%)$ patients had a poor nutritional status on clinical grounds. Of these, 16 were alcoholics.

FEVER

Only 1 patient was febrile on admission. He was found to have an acute exacerbation of chronic bronchitis. He had smoked cigarettes excessively for over 10 years and drank alcohol heavily too.

\section{ARRHYTHMIA}

All the patients were in sinus rhythm on admission. Eight of them had multifocal ventricular ectopics. These ectopics were presumed to be induced by digitalis in 2 patients; 3 others were alcoholics.

\section{MURMURS}

Thirty-four $(68 \%)$ patients had apical pansystolic murmurs of mitral regurgitation on admission. This murmur persisted in only 17 patients after successful treatment. Of the 34 patients with mitral re- gurgitation, 7 had tricuspid regurgitation in addition. The latter, however, disappeared with recovery, except in 2 patients. Two other patients who had no regurgitation of the tricuspid valve on admission later developed this on follow-up. All the patients had a third sound.

\section{OPTIC FUNDI}

Five of the patients had grade I changes according to the Wagener and Keith classification (1939).

\section{OTHER FINDINGS}

Three patients had evidence of renal disease. One had non-functioning kidneys on intravenous pyelography. The second patient had bilateral small kidneys while the third died and was found at necropsy to have bilateral contracted granular kidneys consistent with arteriolonephrosclerosis.

Ten patients had $\mathrm{Hb}$ genotype AS. One other patient had $\mathrm{Hb}$ genotype $\mathrm{AC}$; the rest were $\mathrm{AA}$.

Two patients had cerebrovascular accidents thought to be embolic. Both of them recovered though they had residual hemipareses.

\section{Discussion}

The concept of reactive hypertension, 'Sahli's Hochdruckstauung' (Akinkugbe, 1972; Brockington, 1974), regarded as a feature of cardiomegaly of unknown origin implies a rise in blood pressure as a result of heart failure. It is well recognised that there is increased catecholamine secretion and sodium retention in heart failure (Oram, 1971); these are factors that tend to raise the blood pressure. However, a rise of blood pressure in heart failure occurs more often and in a more pronounced way in primary myocardial disease (Massumi et al., 1965; Brockington, 1972).

Oakley (1972) and Brockington (1972) recently proposed that cardiomegaly of unknown origin is really hypertensive heart failure in disguise. They pointed out that a failing left ventricle cannot achieve an increase in mean blood pressure and that there are well documented hypertensives who lose the need for hypotensive drugs as their hearts get larger and fail. Brockington (1974) also compared the epidemiology, clinical picture, course, and pathology of cardiomegaly of unknown origin in Nigerians with hypertensive heart failure and found that they were similar except that cardiomegaly of unknown origin was more resistant to treatment.

Goodwin (1972b) on the other hand showed that the heart in hypertensive heart disease was different structurally from the heart in cardiomegaly of unknown origin. The heart in the former is more hypertrophied than dilated while that of the latter 
shows more cavity dilatation than hypertrophy. $\mathrm{He}$ also showed that while coronary artery disease was common in hypertension, it was rare in cardiomegaly of unknown origin. The electrocardiograms of the two diseases are different and the phase of hyperfunction or hypertrophy described by Meerson (1962) in his experimental work on cardiac hypertrophy is not seen in cardiomegaly of unknown origin.

There is little agreement at what level hypertension can be considered the cause of, rather than a consequence of myocardial failure (Brigden, 1957; Massumi et al., 1965; World Health Organization, 1965; Brockington, 1974). At Ibadan, considerable difficulty often exists in separating cardiomegaly of unknown origin from hypertensive heart failure which is also common (Akinkugbe, 1972). Therefore, in this study an arbitrary diastolic level of $100 \mathrm{mmHg}$ and below was chosen as compatible with cardiomegaly of unknown origin.

The patients in this study can broadly be divided into two groups. Both groups responded to routine management of heart failure on admission with frusemide as the diuretic. However, on discharge, with the therapy unchanged, the first group continued to do well while the second group relapsed with raised blood pressure; they improved only when the diuretic was changed to a thiazide.

The results show that not all Nigerians with cardiomegaly of unknown origin have raised blood pressure when they are in heart failure. They also show that the clinical course of the patients who are normotensive when in heart failure is different from those with mild hypertension. If hypertension is a consequence of their heart failure, it is difficult to explain why all the patients did not present with mildly raised blood pressures and why their clinical course was different. It seems more likely that the hypertension was contributing to the morbidity of the patients in the second group and the improvement in their heart failure was consequent on the lowering of their blood pressure. The factors which lowered their blood pressure in hospital were bed rest, low salt diet, and frusemide. As out-patients, because of the unrestricted activity and salt intake and the lack of effective control of their blood pressure by frusemide, their condition worsened. They, however, improved when a thiazide diuretic, a more effective hypotensive (Anderson et al., 1971), was substituted. Such patients if treated with thiazides initially and as out-patients, may continue to maintain normal blood pressures and remain out of heart failure. If, however, the diuretic is discontinued, a rise in blood pressure may occur tilting them into heart failure (Falase, unpublished observations). This, we believe, explains why the hypertension in cardiomegaly of unknown origin is transient, occurs only when the patient is in heart failure, and improves with treatment. The fact that some of the patients required methyldopa, a known hypotensive, to improve the heart failure and that the 12 patients observed on digoxin alone after recovery from heart failure showed an initial rise in blood pressures before they had symptoms of heart failure, strongly suggest that these patients are hypertensives.

As shown at angiography (Fig. 3) and in the single case who died, the hearts of these patients showed more cavity dilatation than hypertrophy. These are not the typical hearts seen in hypertension (Goodwin, 1972b). In a recent necropsy study at Ibadan, however, it was observed that large flabby hearts were not restricted to cardiomegaly of unknown origin but could occur in established hypertensive heart disease (Attah and Falase, 1977).

In the present study, 14 hypertensive and 6 normotensive patients were alcoholics. Of the 28 female patients, $20(71 \%)$ were multiparous. Only 1 had symptoms of heart failure within 6 months of delivery confirming the observation that postpartum cardiac failure is less common in the southern part of Nigeria than in the northern part (Ladipo, 1976). Alcohol, however, is known to cause myocardial disease (Brigden and Robinson, 1964; Burch and De Pasquale, 1968). Hypertension, therefore, may have two possible roles in causing the heart disease of patients with cardiomegaly of unknown origin. They may be long-standing hypertensives as suggested by Brockington (1974). Myocardial hypertrophy as a result of hypertension produces an imbalance between oxygen supply and demand causing myocardial hypoxia (Ibrahim and Tarazi, 1975). Such anoxic fibres may be more susceptible to alcohol and other injurious factors. The heart of a long-standing hypertensive who also consumed alcohol excessively, therefore, may, at a stage from repeated damage, become unable to withstand the afterload and, therefore, fails. Blood pressure then drops as a result of loss of myocardial function as postulated by Oakley (1972) and Brockington (1972). This may explain why the presenting blood pressure is low. On the other hand, these patients might have already had myocardial damage produced by these injurious factors but remain compensated. If they then develop hypertension, the hearts become unable to withstand the afterload, and failure supervenes at a relatively low level of diastolic blood pressure. Unfortunately, the premorbid pressures of our patients are not known and as such it is difficult to know which mechanism is operative.

In conclusion, not all Nigerians with cardio- 

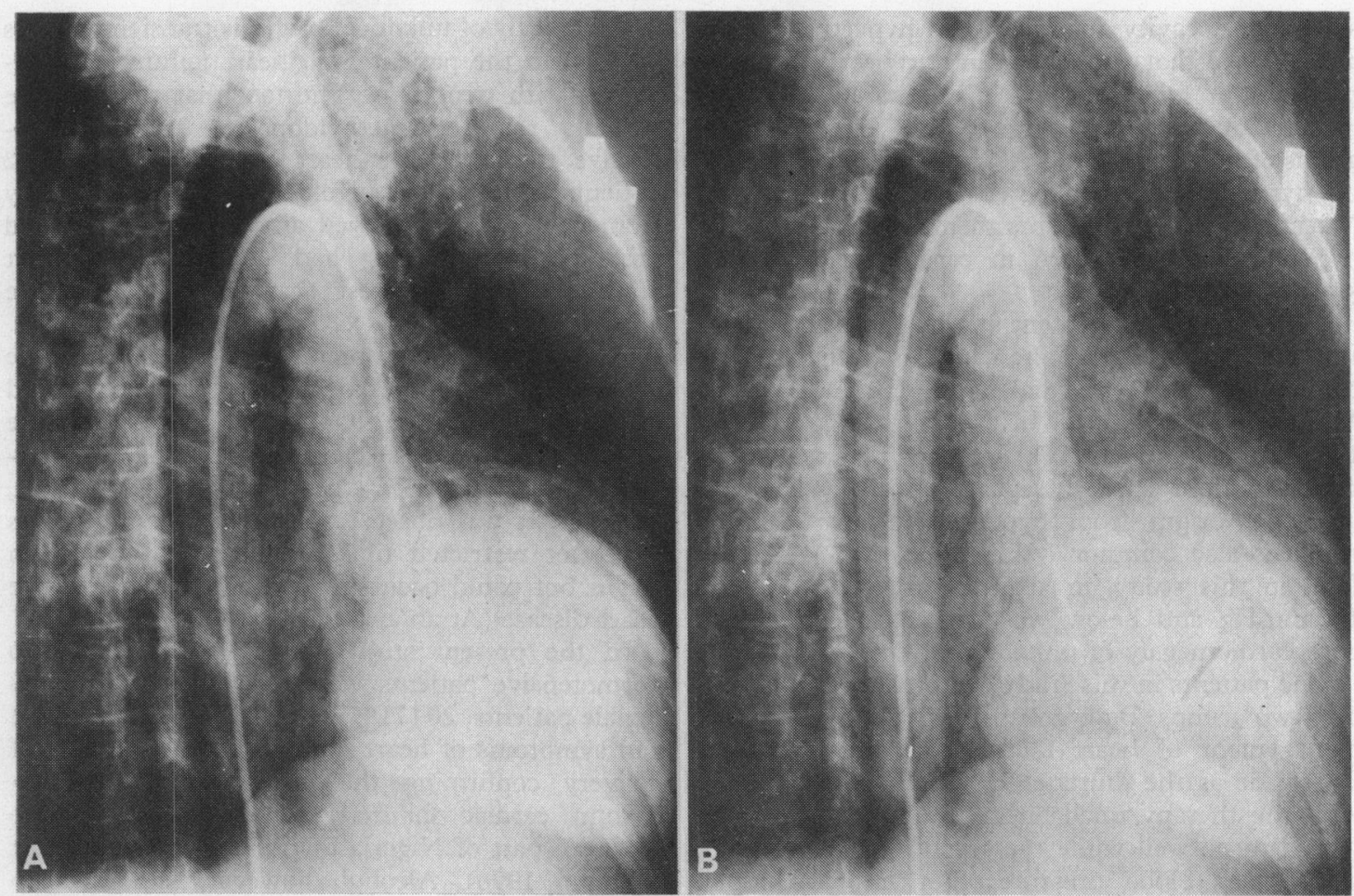

Fig. 3 Left ventriculogram of case 39. Films taken during systole $(A)$ and diastole (B) showing a dilated, poorly contractile left ventricle.

megaly of unknown origin are hypertensives. The mild hypertension seen in some of the patients probably contributes to their morbidity and is not a result of their heart failure. They, however, have a greater degree of myocardial damage compared with other hypertensives. Thus, it may not be true to regard hypertension as the sole cause of their heart failure. Hypertension may be acting together with other factors such as alcohol to produce the severe myocardial damage seen in cardiomegaly of unknown origin.

\section{References}

Akinkugbe, O. O. (1972). High Blood Pressure in the African. Churchill Livingstone, Edinburgh.

Anderson, J., Godfrey, B. E., Hill, D. M., Munro-Faure, A. D., and Sheldon, J. (1971). A comparison of the effects of hydrochlorothiazide and of frusemide in the treatment of hypertensive patients. Quarterly fournal of Medicine, 40, 541-560.

Antia, A. U. (1968). Idiopathic cardiomegaly in children. Cardiologia, 52, 41-43.

Attah, E. B., and Falase, A. O. (1977). Large flabby hearts in hypertension. American Heart fournal. In the press.
Becker, B. J. P., Chatgidakis, C. B., and Van Lingen, B. (1953). Cardiovascular collagenosis with parietal endocardial thrombosis. Circulation, 7, 345-356.

Brigden, W. (1957). Uncommon myocardial diseases. The non-coronary cardiomyopathies. Lancet, 2, 1179-1184.

Brigden, W., and Robinson, J. F. (1964). Alcoholic heart disease. British Medical fournal, 2, 1283-1289.

Brockington, I. F. (1972). Debate: That congestive cardiomyopathy is really hypertensive heart disease in disguise. Postgraduate Medical fournal, 48, 777-789.

Brockington, I. F. (1974). Heart muscle disease in Nigeria. M.D. Thesis, University of Cambridge.

Brockington, I. F., and Bohrer, S. P. (1970). Enlargement of the aortic shadow in Nigerian heart muscle disease. Acta Cardiologica, 25, 344-356.

Burch, G. E., and DePasquale, N. P. (1968). Alcoholic cardiomyopathy. Cardiologia, 52, 48-56.

Cockshott, W. P., Thorpe, G. J., and Ikeme, A. C. (1967). Radiological aspects of heart muscle disease in Nigerian adults. Circulation, 36, 460-467.

Davies, R. R., Marvel, R. J., and Genovese, P. D. (1951). Heart disease of unknown etiology. American Heart fournal, 42, 546-565.

Edington, G. M., and Hutt, M. S. R. (1968). Idiopathic cardiomegaly. General and pathology. Cardiologia, 52, 3343.

Edington, G. M., and Jackson, J. G. (1963). The pathology of heart muscle disease and endomyocardial fibrosis in Nigeria. Fournal of Pathology and Bacteriology, 86, 333-344. 
Fishberg, A. M. (1940). Heart Failure, 2nd edn. Kimpton, London.

Fowler, N. O. (1964). Classification and differential diagnosis of the myocardiopathies. Progress in Cardiovascular Diseases, 7, 1-16.

Goodwin, J. F. (1972a). Clarification of the cardiomyopathies. Modern Concepts of Cardiovascular Disease, 41, 41-46.

Goodwin, J. F. (1972b). Debate: That congestive cardiomyopathy is really hypertensive heart disease in disguise. Postgraduate Medical fournal, 48, 777-789.

Goodwin, J. F., and Oakley, C. M. (1972). The cardiomyopathies. British Heart fournal, 34, 545-552.

Harvey, W. P., Segal, J. P., and Gurel, T. (1964). The clinical spectrum of primary myocardial disease. Progress in Cardiovascular Diseases, 7, 17-42.

Higginson, J., Gillanders, A. D., and Murray, J. F. (1952). The heart in chronic malnutrition. British Heart fournal, 14. 213-224.

Ibrahim, M. M., and Tarazi, R. C. (1975). The heart in hypertension. Cardiovascular Clinics, 7, 121-133.

Ladipo, G. O. A. (1976). Cardiac failure in Ahmadu Bello University Teaching Hospital, Zaria. A comparison with sister institutions in the Southern States of Nigeria. Paper presented at the 5th Annual Scientific meeting of the Nigerian Cardiac Society.

Massumi, R. A., Rios, J. C., Gooch, A. S., Nutter, D., De Vita, V. T., and Datlow, D. W. (1965). Primary myocardial disease. Circulation, 31, 19-41.

Mattingly, T. W. (1961). Clinical features and diagnosis of primary myocardial disease (1). Modern Concepts of Cardiovascular Disease, 30, 677-682.
Meerson, F. Z. (1962). Compensatory hyperfunction of the heart and cardiac insufficiency. Circulation Research, 10, 250-258.

Oakley, C. M. (1972). Debate: That congestive cardiomyopathy is really hypertensive heart disease in disguise. Postgraduate Medical fournal, 48, 777-789.

Oram, S. (1971). Clinical Heart Disease. Heinemann, London. Osuntokun, B. O., Akinkugbe, F. M., Francis, T. I., Reddy, S., Osuntokun, O., and Taylor, G. O. L. (1971). Diabetes mellitus in Nigerians: a study of 832 patients. West African Medical fournal, 20, 295-312.

Parry, E. H. O. (1968). Idiopathic cardiomegaly. Clinical diagnosis. Cardiologia, 52, 36-41.

Reisinger, J. A., and Blumenthal, B. (1941). Myocardial degeneration with hypertrophy and failure of unknown cause. American Heart fournal, 22, 811-824.

Stuart, K. L., and Hayes, J. A. (1963). A cardiac disorder of unknown aetiology in Jamaica. Quarterly fournal of Medicine, 32, 99-114.

Tobin, J. R., Jr., Driscoll, J. F., Lim, M. T., Sutten, G. C., Szanto, P. B., and Gunnar, R. M. (1967). Primary myocardial disease and alcoholism. Circulation, 35, 754-764.

Wagener, H. P., and Keith, N. M. (1939). Diffuse arteriolar disease with hypertension and the associated retinal lesions. Medicine, 18, 317-430.

World Health Organization (1965). Cardiomyopathies. Bulletin of the World Health Organization, 33, 257-264.

Requests for reprints to Dr. A. O. Falase, Department of Medicine, University College Hospital, Ibadan, Nigeria. 